\title{
Rancang Bangun Sistem Informasi Berkendara Berbasis Arduino
}

\author{
Peter William $^{1} \quad$ Yuwono Marta Dinata ${ }^{2}$ \\ Program Studi Teknik Informatika, Universitas Ciputra \\ email: ${ }^{1}$ pwilliam@student.ciputra.ac.id, 2yuwono.dinata@ciputra.ac.id
}

\begin{abstract}
Abstrak: Pada masa kini dalam menentukan posisi dari suatu keberadaan kendaraan secara akurat memiliki peran yang penting, terutama untuk keperluan navigasi. Beragam jenis alat Global Positioning System (GPS) yang terdapat di pasaran digunakan dalam navigasi tetapi kebanyakan memberikan layanan yang kurang lebih sama. Layanan tersebut yaitu hanya dapat memberikan solusi dengan penyimpanan data pada kartu memory $S D$ card. Dengan melihat hal itu maka pada penelitian ini memberikan suatu alternatif solusi yaitu dengan menambahkan kartu sim card dan mikrokontroler Arduino yang dilengkapi dengan GPS. Hal ini dapat menjadi keunggulan sistem yang telah dibuat yaitu dapat memberikan lokasi kendaraan terpantau secara online. Sistem yang dibuat ini berbasiskan geolocation. Pengujian sistem ini dilakukan dengan metode statik dan dinamik. Metode statik dilakukan pada saat GPS berhenti di tempat, sedangkan metode dinamik di lakukan pada saat GPS dalam keadaan kendaraan berjalan. Hasil yang didapatkan yaitu terdapat delay pada pengambilan data berikutnya kurang lebih 30 detik baik pengujian statik maupun dinamik.
\end{abstract}

Kata Kunci: pelacakan, GPS, Arduino, Geolocation

\begin{abstract}
At present in determining the position of a truly important place, it is important for navigation purposes. Various types of Global Positioning System (GPS) devices that are on the market are used in navigation but provide more or less the same service. The service is only able to provide solutions with data storage on the SD card memory card. By looking at it, this study provides an alternative solution, namely by adding a sim card and Arduino microcontroller equipped with GPS. This can be a system advantage that has been made that can provide the location of the vehicle monitored online. System created based on this geolocation. Testing this system is done by static and dynamic methods. Static methods are carried out when the GPS stops in place, while the dynamic method is carried out when the GPS is in a vehicle's running condition. The results obtained are postponed in the next data retrieval for approximately 30 seconds both static and dynamic testing.
\end{abstract}

Keywords: tracking, GPS, Arduino, Geolocation

\section{PENDAHULUAN}

Kecelakaan dalam berlalu lintas cukup berada di angka yang memprihatikan dan perlu dicarikan solusinya. Hal ini diperkuat dari data Global Status Report on Road Safety [1] yang menyatakan bahwa terdapat kurang lebih 1,24 juta jiwa yang meninggal tiap tahun di seluruh penjuruh dunia dan juga terdapat sekitar 20-50 juta jiwa yang membutuhkan perawatan medis dari kecelakaan lalu lintas yang terjadi. Data tersebut menunjukkan analisa yang menyatakan penyebab utama dari kematian para remaja di sebabkan oleh kecelakaan lalulintas dengan jumlah nominal rata-rata mencapat 1000 anak per hariannya dengan variasi usia $10 \mathrm{~s} / \mathrm{d} 24$ tahun. Sedangkan di Indonesia kecelakaan dalam berlalu lintas termasuk dalam penyebab kematian terbesar ketiga setelah kematian yang di sebabkan penyakit jantung koroner dan tuberculosis yang telah di teliti oleh pihak World Health Organization (WHO). Kecelakaan lalu lintas di Indonesia pada umumnya dilakukan oleh Komite Nasional Keselamatan Transportasi). Data yang didapatkan bahwa kecelakaan yang terjadi sampai korban meninggal maupun luka-luka terdapat 
bahwa \pm 6 kali kecelakaan lalu lintas jalan terjadi tiap tahun [2].

Berdasarkan kutipan dari Riskedas 2013 terdapat peningkatan populasi tertentu yang mengalami cedera dari $7,5 \%$ menjadi $8,2 \%$. Penyebab luka yang membutuhkan perhatian medis terbanyak kedua merupakan kecelakaan yang menggunakan roda dua (kendaraan bermotor) $(40,6 \%)$. Pada Kota Surabaya sendiri mempunyai jumlah kecelakaan lalu lintas terbanyak yang berada di posisi ke lima pada tahun 2013 dengan jumlah kecelakaan sebesar 837 kejadian [3].

Hal lain yang menjadi perhatian selain tingkat kecelakaan kendaraan adalah tentang keamanan kendaraan. Pada saat ini hampir setiap orang memiliki kendaraan pribadi, namun dari segi keamanan banyak terjadi pencurian kendaraan di sekitar tempat parkir. Maka dari itu keamanan pada sebuah kendaraan menjadi sangatlah penting [4]. Teknologi (Global Positioning System) GPS dan (Global System for Mobile) GSM dapat digunakan untuk memantau lokasi kendaraan. Melalui teknologi tersebut dapat diintegrasikan untuk menggabungkan GPS dan GSM yang menjadi dasar penelitian yang akan dilaksanakan. Teknolog ini sangat flexible untuk diterapkan dimanapun, ada yang diterapkan pada penggunaan helm, sehingga apabila pengendara belum menggunakan helm maka kendaraan tidak mau menyala dan GPS dan GSM membantu mengetahui lokasi jika terjadi kecelakaan [5]. Pada penelitan ini sistem yang dibuat dapat secara terus menerus memantau kendaraan yang sedang berjalan dan di tampilkan dalam bentuk peta melalui Google Map. Kendaraan yang telah menggunakan GPS tracking ini dapat memberikan salah satu altenatif keamaan kendaraan. Sehingga GPS tracking ini digunakan sebagai langkah preventif dari pencurian. Pemilik kendaraan maupun polisi dapat mengikuti sinyal yang di pancarkan melalui GPS tracking tersebut untuk mengetahui lokasi dari pencuri kendaraan. Peneliti sebelumnya juga penah menggunakan Arduino Uno yang di gabungkan dengan GPS+GSM untuk pengumpulan data [6], pada penelitian ini data langsung ditampilkan ke website.

Pada penelitian ini menggunakan beberapa dasar teori yaitu Arduino Uno, GPS, GSM Module, dan Geolocation Maps. Arduino merupakan salah satu mikrokontroler yang dirancang dengan tujuan siapapun dapat dengan mudah untuk menggunakan dan melakukan ujicoba dengan lebih cepat [7]. Tipe Arduino Uno, Arduino Mega, Arduino Lilipad dll. Pada penelitian ini menggunakan Arduino Uno yang ditambahkan

Ethernet Shield untuk mengirimkan data ke internet. Arduino Uno dipilih dalam penelitian ini karena ukurannya yang relatif kecil, sumber daya yang digunakan juga rendah dan cukup untuk mengakomodasi kebutuhan penelitian yang dilakukan, gambar dari Arduino Uno dapat dilihat pada

Gambar 1 Arduino Uno (sumber https://store.arduino.cc/usa/arduino-uno-rev3).

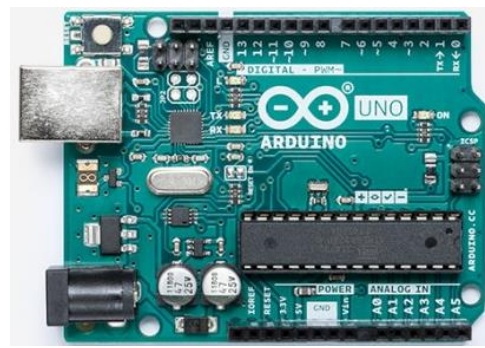

Gambar 1 Arduino Uno (sumber https://store.arduino.cc/usa/arduino-uno-rev3)

Teknologi GPS merupakan teknologi yang digunakan oleh beberapa peneliti sebelumnya untuk melakukan tracking posisi dimana kendaraan tersebut berada dan mengurangi kecepatan kendaraan jika ternyata memang kendaraan tersebut dicuri [4].

Global Positioning System (GPS) merupakan satu-satunya yang sepenuhnya menggunakan Global Navigation System (GNSS). GPS untuk dapat bekerja secara optimal maka menggunakan antara 24 dan 32 satelit Medium Earth Orbit yang mentransmisikan sinyal gelombang mikro yang memungkinkan penerima GPS untuk menentukan lokasi, kecepatan, arah, dan waktu dengan tepat. Sedangkan pada penerima GPS, menerima sinyal dari setidaknya tiga satelit untuk menghitung jarak dan menggunakan teknik triangulasi untuk menghitung posisi dua dimensi (lintang dan bujur) atau setidaknya empat satelit untuk menghitung posisi tiga dimensi (lintang, bujur dan ketinggian) [8].

Sistem yang digunakan diletakan di bagian kendaraan yang tidak terlihat oleh yang melakukan pencurian [8]. Pada penelitian ini juga menggunakan teknologi GPS/GSM yang juga diterapkan untuk melakukan tracking secara online dan menampilkan secara real time melalui 
peta online yang dapat diakses melalui website. Pada penelitian ini, digunakan modul GPS dengan seri SIM808, yang dapat dilihat pada Gambar 2, sedangkan GSM Module dapat dilihat pada

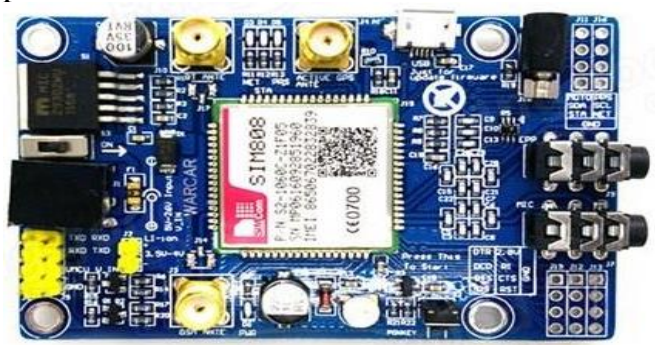

Gambar 2 Module GPS

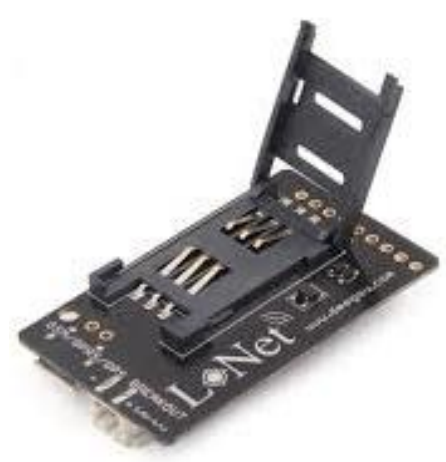

Gambar 3 GSM Module

\section{METODE PENELITIAN}

Untuk melakukan penelitian ini, diambil sebuah contoh kasus untuk pemonitoran kendaraan yang dimiliki kendaraan agent travel, maka interview dilakukan untuk mendapatkan beberapa informasi. Berdasarkan hasil wawancara tersebut ditemukan bahwa sistem yang dimiliki sekarang mempunyai kelemahan dimana pengecekan data lokasi serta kecepatan pengendara hanya dapat dilihat saat kendaraan sudah berada pada kantor pusat untuk di ambil datanya. Kemudian masalah yang lain adalah tidak terpantaunya posisi driver sehingga beberapa customer menunggu dengan tidak pasti. Maka dari itu, penelitian ini menampilkan sistem yang real time berbasis website, yang menggabungan antara modul GPS dengan Arduino, sehingga pemilik kendaraan dapat mengetahui lokasi kendaraan. Arsitektur dari penelitian ini dapat dilihat pada Gambar 4. GPS tracking yang diletakkan pada mobil melakukan pemetaan lokasi mobil berdasarkan GPS yang ada, untuk dapat melakukan pemetaan posisi pada mobil dibutuhkan beberapa stelit GPS. Arduino Uno ditanamkan di dalam mobil yang digunakan. Arduino tersebut telah dilengkapi dengan modul GPS dan GSM, data tersebut akan dikirimkan ke server. Data yang dikirimkan berupa waktu, data tanggal, kecepatan perpindahan lokasi a ke b , serta data lokasi (latitude dan longitude).

Setelah lokasi mobil telah didapatkan, data dari lokasi mobil pada waktu pengambilan data akan dikirim menggunakan modul GSM ke database cloud. Untuk menampilkan rute mana saja yang telah dilalui maka data kendaraan perlu disimpan dahulu deserver dan kemudian baru diolah. Dari data yang ada dapat diketahui lokasi maupun kecepatannya yang ditampilkan pada website menggunakan Google Map API.

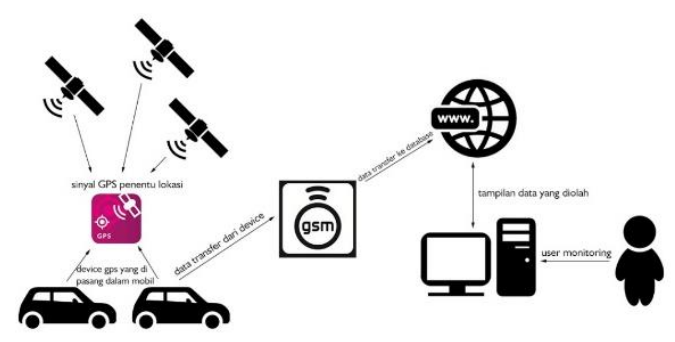

Gambar 4 Arsitektur Penelitian

\section{Perancangan Perangkat Keras}

Perangkat keras yang digunakan pada penelitian ini dapat dilihat pada Gambar 5. Perangkat keras yang dibutuhkan berupa Arduino UNO, SIM808 Board, GSM Antena, GPS Antena dan power supply untuk Arduino Uno dan SIM808. SIM808 langsung bisa di masukkan ke socket pin dari Arduino. Dengan pen-setting-an yang sangat mudah ini dapat mempercepat proses untuk melakukan penelitian.

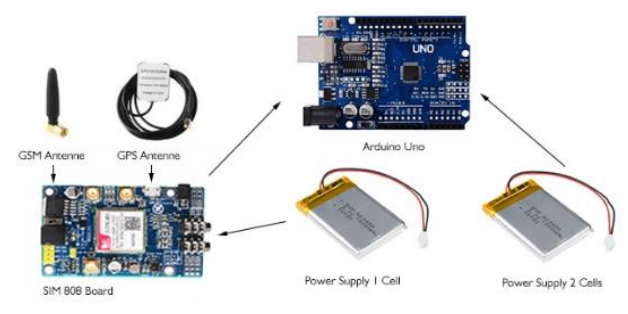

Gambar 5 Desain Perangkat Keras

\section{Perancangan Perangkat Lunak}

Perancangan perangkat lunak yang telah dilakukan dapat dilihat pada diagram alir program yang dapat dilihat pada Gambar 6. Proses awal 
dimulai pada Arduino diawali dengan melakukan setup yang dijalankan pertama kali saat Arduino Uno beserta Sim808 Board mendapatkan catu daya dari power supply. Proses inisialisasi ini adalah melakukan inisialisasi serial baudrate dan GPS.

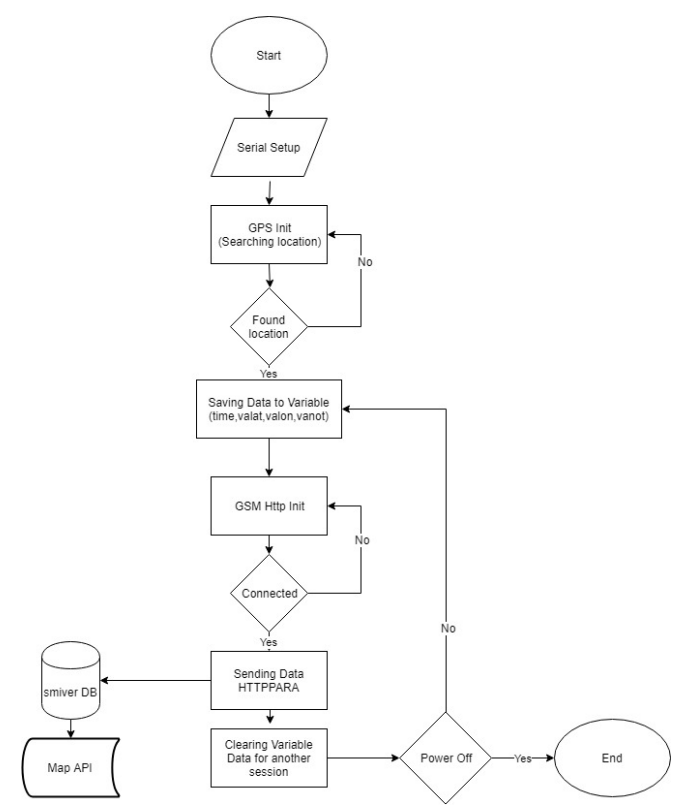

Gambar 6 Diagram alir perangkat lunak

Proses selanjutnya GPS akan mencari lokasi dari antenna yang terhubung dengan sim808. Saat pencarian terdapat dua kondisi yaitu lokasi GPS ditemukan maupun tidak ditemukan. Jika lokasi GPS ditemukan maka proses selanjutkan mengambil data dari GPS berupa Timestamp yang berupa waktu pengambilan data, latitude dan longitude (lokasi x \& y pada peta), beserta knot yang diconvert dalam satuan kilometer. Sedangkan apabila lokasi GPS tidak ditemukan maka akan mencari terus sampai menemukan lokasi karena untuk menemukan lokasi dari GPS membutuhkan waktu beberapa menit sampai menemukan lokasi dari GPS yang digunakan.

\section{Use Case Diagram}

Use case diagram dari penelitian ini dapat dilihat pada Gambar 7. Pada use case diagram ini terdapat tiga user yaitu travel agent (admin) dan traveler. User melakukan beberapa hal seperti dapat mengakses data lokasi, menambahkan kendaraan dan driver, mengganti data, melihat keseharian driver saat membawa kendaraan. User yang dimaksudkan di sini adalah travel agent. Sedangkan untuk traveler hanya bisa memantau/melihat informasi kendaraan melalui website.

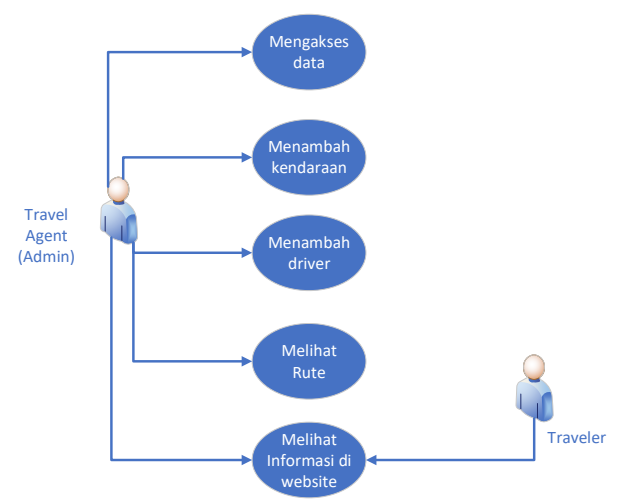

Gambar 7 Use case diagram sistem

\section{Implementasi}

Setelah perancangan perangkat keras dan lunak yang dilakukan maka tahap berikutnya adalah melakukan implementasi. Implementasi yang dilakukan yaitu implementasi Rangkaian, implementasi perangkat lunak, implementasi website.

\section{Implementasi rangkaian}

Rangkaian yang digunakan terdiri dari Arduino Uno dan GPS+GSM Sim808 Modul. Arduino Uno berfungsi sebagai pemrosesan maupun yang menjalakan perintah kode yang telah diupload ke dalam mikrokontroler tersebut, sedangkan GPS+GSM Sim808 digunakan sebagai bagian pendukung dalam penggunaan GPS maupun GSM untuk mendapatkan data yang diinginkan, Gambar rangkaian yang digunakan pada penelitian ini dapat dilihat pada Gambar 8 .

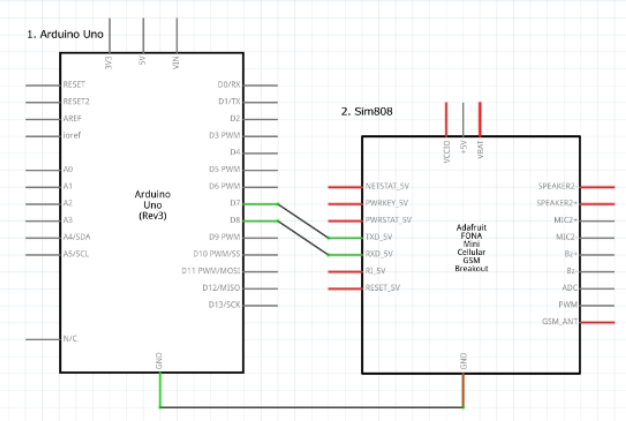

Gambar 8 Rangkaian Perangkat Keras 
Koneksi pin dari perangkat keras dapat dilihat pada Tabel 1.

Tabel 1 Koneksi perangkat keras

\begin{tabular}{|c|c|}
\hline Arduino Uno & SIM808 EVB \\
\hline \multicolumn{2}{|c|}{ Digital Pin 7 (D7) $\rightarrow$ Digital pin TXD 5v } \\
\hline \multicolumn{2}{|c|}{ Digital Pin 8 (D8) $\rightarrow$ Digital pin RXD 5v } \\
\hline $\begin{array}{l}\text { Digital Pin Grou } \\
\text { Ground (GND) }\end{array}$ & D) $\rightarrow$ Digital Pin \\
\hline
\end{tabular}

\section{Implementasi perangkat lunak}

Program dibuat dengan melakukan inisialisasi library yang digunakan. Tahap berikutnya adalah melakukan setup agar komunikasikan antara Sim808 dengan Arduino Uno dapat saling terhubung, seperti potongan Kode 1.

Kode 1 inisialisasi

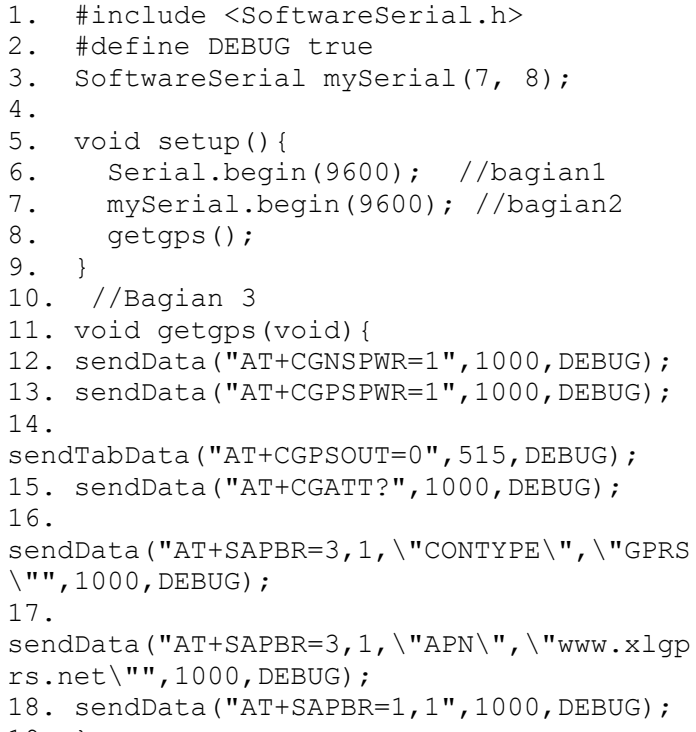

Penjelasan dari Kode 1 sebagai berikut pada bagian Setup, terdiri dari tiga bagian yaitu yang pertama, melakukan setup untuk serial dengan baud rate 9600, hal ini berfungsi untuk menjalankan komunikasi serial. Bagian yang kedua setup untuk komunikasi serial tambahan
mySerial.begin(9600); hal ini berfungsi untuk memaksimalkan pin Arduino yang dapat digunakan sebagai pin komunikasi serial. Bagian yang ketiga adalah getgps(); yang berfungsi untuk menghubungkan koneksi dari modul dengan sim card agak terhubung dengan internet.

Bagian berikutnya adalah parsing data menggunakan void sendData yang berfungsi untuk mengkomunikasikan penggunaan serial dengan modul sim808 supaya dapat menjalankan dengan menggunakan ATcommands, seperti pada Kode 2.

\section{Kode 2 Parsing Data}

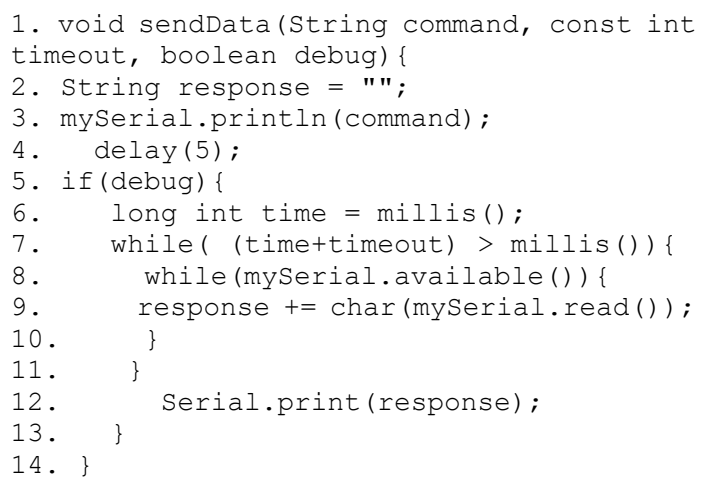

Berikutnya merupakan program untuk melakukan pengiriman data bagian yang berperan adalah void http. void http berfungsi untuk mengirimkan data yang telah disimpan pada varibel masing-masing kemudian diarahkan untuk disimpan ke dalam database website yang telah dirancang, kode programnya dapat dilihat pada Kode 3.

Kode 3 Pengiriman Data

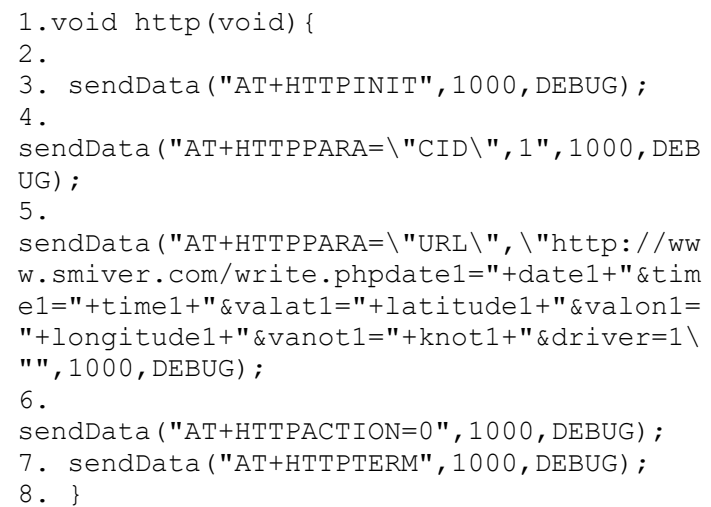




\section{Implementasi website}

Halaman awal dari website yang digunakan untuk menampillkan data dapat dilihat pada Gambar 9. Pada bagian Gambar 9, terdapat no 1 yang menunjukkan untuk mengakses bagian menú. Menu tersebut berisi Home, About, Car Tracking, dan Contact. Menu Home berfungsi untuk menuju halaman awal, menu about berisi penjelasan mengenai aplikasi ini, car tracking berisi hasil monitoring data dan menu contact berisi informasi kontak person jika ada orang yang ingin bertanya lebih lanjut. Saat menu yang ditunjukan no satu di akses maka akan muncul seperti pada Gambar 10.

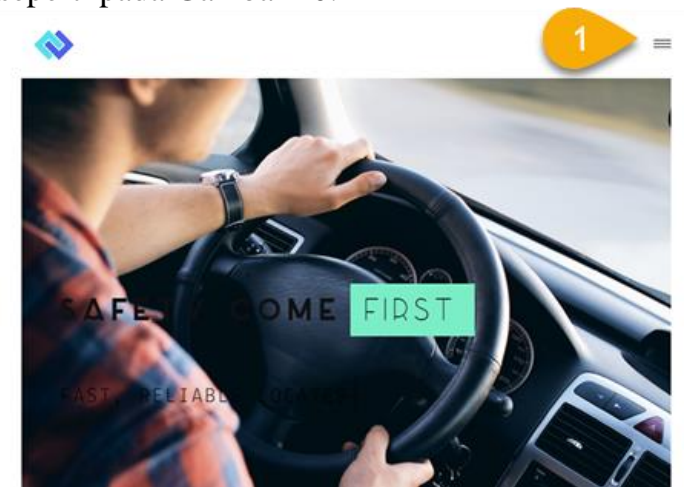

Gambar 9 Tampilan Halaman Awal (Landing Page)

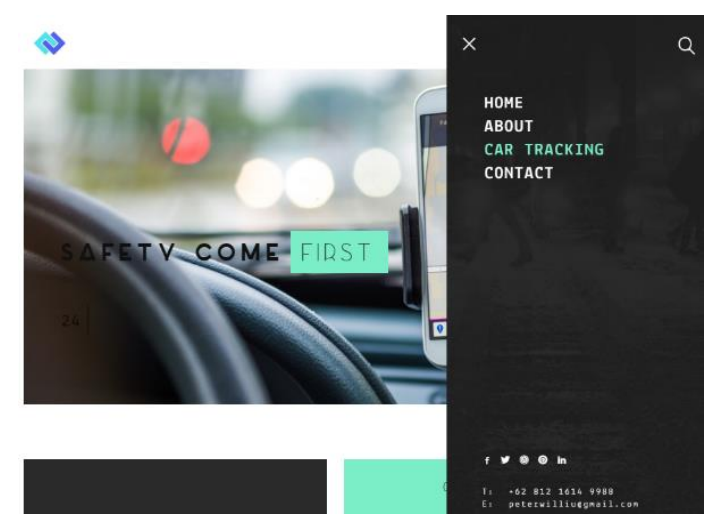

Gambar 10 Menu Saat diakses

Pada bagian menu Home jika diakses akan menampilkan tampilan seperti pada Gambar 11 . Sedangkan untuk menu Car Tracking bila diakses maka akan menampilkan informasi berupa peta dari lokasi alat GPS, kecepatan kendaraan pada saat driver membawa kendaraan serta menampilkan kecepatan rata-rata. Sedangkan bagi pemilik kendaraan(Travel Agent) dapat mengakses halaman yang digunakan untuk melihat rute apa saja yang digunakan oleh driver dengan menekan tombol "Daily Route" yang akan menampilkan rute-rute yang di lewati. Menu Car Tracking dapat dilihat pada Gambar 12.

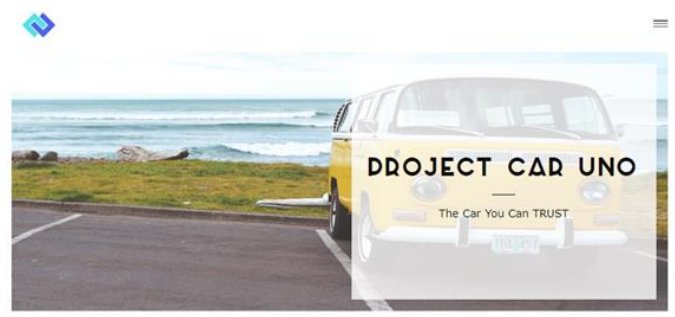

Gambar 11 Menu Home yang diakses

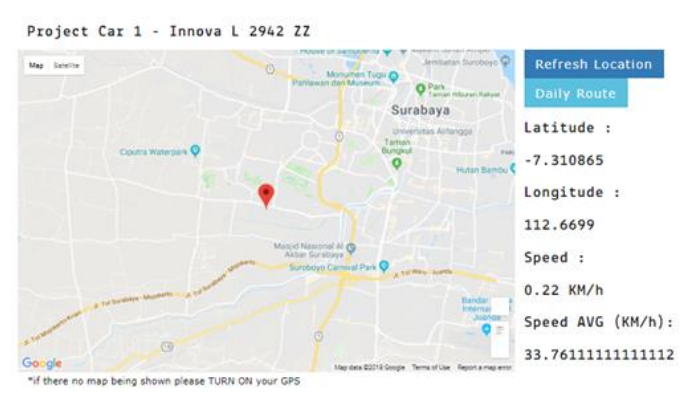

Gambar 12 Menu Car Tracking

Sedangkan tampilan rute dari kendaraan yang telah lalui dapat dilihat pada Gambar 13. Innova L 2942 ZZ

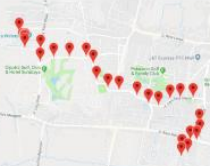

Gambar 13 Rute yang dilalui

\section{HASIL DAN PEMBAHASAN}

Pengujian pada penelitian ini dibagi menjadi dua bagian yaitu bagian statik dan dinamik. Bagian statik adalah pengujian menampilkan data saja pada serial monitor. Bagian dinamik adalah pengujian secara real yang dilakukan dengan cara benar-benar menyalakan alat tersebut dan membawa mengelilingi rute, dalam hal ini rute yang di tempuh adala jalan dari rumah peneliti sampai ke kampus. Hasil pengujian yang di bagian statik dapat dilihat pada Gambar 14 . 
Peter, W, dkk /Journal of Technology and Informatics (JoTI) Vol.1, No.1, Oktober 2019, 31-40

Hasil detail pengujian statik dapat dilihat pada Tabel 2 .

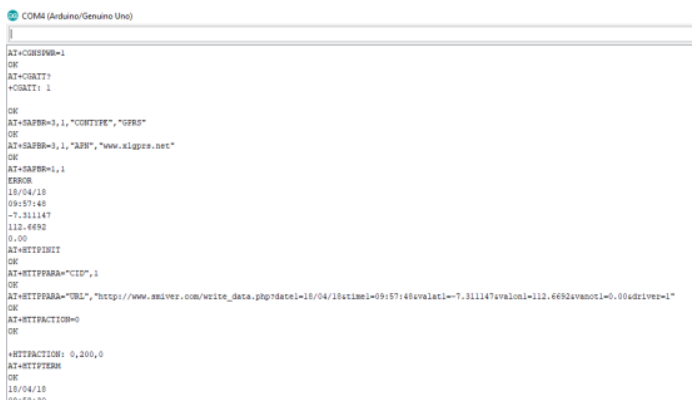

Gambar 14 Hasil pengujian static

Tabel 2 Hasil Pengujian Statik

\begin{tabular}{|c|c|c|c|c|c|c|}
\hline No & Tanggal & Waktu & $\begin{array}{l}\text { Latitu } \\
\text { de }\end{array}$ & $\begin{array}{l}\text { Longitu } \\
\text { de }\end{array}$ & Knot & $\begin{array}{l}\text { Driver } \\
\text { id }\end{array}$ \\
\hline 1 & $18 / 04 / 05$ & $\begin{array}{l}\text { 20:28: } \\
10\end{array}$ & $\begin{array}{l}- \\
7.3109 \\
45\end{array}$ & $\begin{array}{l}112.66 \\
97\end{array}$ & 0.22 & 1 \\
\hline 2 & $18 / 04 / 05$ & $\begin{array}{l}20: 28: \\
43\end{array}$ & $\begin{array}{l}- \\
7.3109 \\
13\end{array}$ & $\begin{array}{l}112.66 \\
97\end{array}$ & 0.19 & 1 \\
\hline 3 & $18 / 04 / 05$ & $\begin{array}{l}\text { 20:30: } \\
57\end{array}$ & $\begin{array}{l}- \\
7.3108 \\
50\end{array}$ & $\begin{array}{l}112.66 \\
97\end{array}$ & 0.46 & 1 \\
\hline 4 & $18 / 04 / 05$ & $\begin{array}{l}\text { 20:31: } \\
32\end{array}$ & $\begin{array}{l}- \\
7.3108 \\
72\end{array}$ & $\begin{array}{l}112.66 \\
97\end{array}$ & 0.19 & 1 \\
\hline 5 & $18 / 04 / 05$ & $\begin{array}{l}\text { 20:32: } \\
06\end{array}$ & $\begin{array}{l}- \\
7.3108 \\
72\end{array}$ & $\begin{array}{l}112.66 \\
97\end{array}$ & 0.00 & 1 \\
\hline 6 & $18 / 04 / 05$ & $\begin{array}{l}20: 34: \\
20\end{array}$ & $\begin{array}{l}- \\
7.3108 \\
52\end{array}$ & $\begin{array}{l}112.66 \\
97\end{array}$ & 0.63 & 1 \\
\hline 7 & $18 / 04 / 05$ & $\begin{array}{l}20: 34: \\
55\end{array}$ & $\begin{array}{l}- \\
7.3108 \\
23\end{array}$ & $\begin{array}{l}112.66 \\
97\end{array}$ & 0.00 & 1 \\
\hline 8 & $18 / 04 / 05$ & $\begin{array}{l}20: 35: \\
28\end{array}$ & $\begin{array}{l}- \\
7.3108 \\
35\end{array}$ & $\begin{array}{l}112.66 \\
97\end{array}$ & 0.19 & 1 \\
\hline 9 & $18 / 04 / 05$ & $\begin{array}{l}\text { 20:36: } \\
02\end{array}$ & $\begin{array}{l}- \\
7.3108 \\
62\end{array}$ & $\begin{array}{l}112.66 \\
97\end{array}$ & 0.22 & 1 \\
\hline 10 & $18 / 04 / 05$ & $\begin{array}{l}\text { 20:36: } \\
36\end{array}$ & $\begin{array}{l}\text { - } \\
7.3108 \\
52\end{array}$ & $\begin{array}{l}112.66 \\
97\end{array}$ & 0.30 & 1 \\
\hline 11 & $18 / 04 / 05$ & $\begin{array}{l}\text { 20:37: } \\
10\end{array}$ & $\begin{array}{l}- \\
7.3108 \\
57\end{array}$ & $\begin{array}{l}112.66 \\
97\end{array}$ & 0.63 & 1 \\
\hline
\end{tabular}

\begin{tabular}{|c|c|c|c|c|c|c|}
\hline No & Tanggal & Waktu & $\begin{array}{l}\text { Latitu } \\
\text { de }\end{array}$ & $\begin{array}{l}\text { Longitu } \\
\text { de }\end{array}$ & Knot & $\begin{array}{l}\text { Driver } \\
\text { id }\end{array}$ \\
\hline 12 & $18 / 04 / 05$ & $\begin{array}{l}20: 37: \\
44\end{array}$ & $\begin{array}{l}7.3108 \\
68\end{array}$ & $\begin{array}{l}112.66 \\
98\end{array}$ & 0.00 & 1 \\
\hline 13 & $18 / 04 / 05$ & $\begin{array}{l}\text { 20:39: } \\
58\end{array}$ & $\begin{array}{l}- \\
7.3108 \\
62\end{array}$ & $\begin{array}{l}112.66 \\
98\end{array}$ & 0.46 & 1 \\
\hline 14 & $18 / 04 / 05$ & $\begin{array}{l}20: 40: \\
33\end{array}$ & $\begin{array}{l}7.3108 \\
92\end{array}$ & $\begin{array}{l}112.66 \\
98\end{array}$ & 0.00 & 1 \\
\hline 15 & $18 / 04 / 05$ & $\begin{array}{l}\text { 20:46: } \\
12\end{array}$ & $\begin{array}{l}- \\
7.3109 \\
03\end{array}$ & $\begin{array}{l}112.66 \\
98\end{array}$ & 0.44 & 1 \\
\hline 16 & $18 / 04 / 05$ & $\begin{array}{l}\text { 20:46: } \\
47\end{array}$ & $\begin{array}{l}7.3109 \\
07\end{array}$ & $\begin{array}{l}112.66 \\
97\end{array}$ & 0.00 & 1 \\
\hline 17 & $18 / 04 / 05$ & $\begin{array}{l}\text { 20:47: } \\
21\end{array}$ & $\begin{array}{l}- \\
7.3108 \\
88\end{array}$ & $\begin{array}{l}112.66 \\
97\end{array}$ & 0.62 & 1 \\
\hline 18 & $18 / 04 / 05$ & $\begin{array}{l}\text { 20:47: } \\
54\end{array}$ & $\begin{array}{l}7.3108 \\
60\end{array}$ & $\begin{array}{l}112.66 \\
97\end{array}$ & 0.70 & 1 \\
\hline 19 & $18 / 04 / 05$ & $\begin{array}{l}\text { 20:48: } \\
27\end{array}$ & $\begin{array}{l}- \\
7.3108 \\
72\end{array}$ & $\begin{array}{l}112.66 \\
97\end{array}$ & 0.00 & 1 \\
\hline 20 & $18 / 04 / 05$ & $\begin{array}{l}\text { 20:49: } \\
00\end{array}$ & $\begin{array}{l}- \\
7.3108 \\
05\end{array}$ & $\begin{array}{l}112.66 \\
97\end{array}$ & 0.00 & 1 \\
\hline 21 & $18 / 04 / 05$ & $\begin{array}{l}\text { 20:49: } \\
32\end{array}$ & $\begin{array}{l}- \\
7.3108 \\
93\end{array}$ & $\begin{array}{l}112.66 \\
98\end{array}$ & 0.37 & 1 \\
\hline 22 & $18 / 04 / 05$ & $\begin{array}{l}\text { 20:50: } \\
05\end{array}$ & $\begin{array}{l}- \\
7.3107 \\
83\end{array}$ & $\begin{array}{l}112.66 \\
98\end{array}$ & 0.14 & 1 \\
\hline 23 & $18 / 04 / 05$ & $\begin{array}{l}\text { 20:50: } \\
39\end{array}$ & $\begin{array}{l}- \\
7.3107 \\
73\end{array}$ & $\begin{array}{l}112.66 \\
98\end{array}$ & 0.00 & 1 \\
\hline 24 & $18 / 04 / 05$ & $\begin{array}{l}\text { 20:51: } \\
13\end{array}$ & $\begin{array}{l}- \\
7.3107 \\
50\end{array}$ & $\begin{array}{l}112.66 \\
98\end{array}$ & 0.41 & 1 \\
\hline 25 & $18 / 04 / 05$ & $\begin{array}{l}20: 55: \\
12\end{array}$ & $\begin{array}{l}- \\
7.3108 \\
47\end{array}$ & $\begin{array}{l}112.66 \\
98\end{array}$ & 1.43 & 1 \\
\hline 26 & $18 / 04 / 05$ & $\begin{array}{l}20: 55: \\
47\end{array}$ & $\begin{array}{l}- \\
7.3107 \\
73\end{array}$ & $\begin{array}{l}112.66 \\
98\end{array}$ & 0.44 & 1 \\
\hline 27 & $18 / 04 / 05$ & $\begin{array}{l}\text { 20:56: } \\
21\end{array}$ & $\begin{array}{l}- \\
7.3107 \\
95\end{array}$ & $\begin{array}{l}112.66 \\
98\end{array}$ & 0.19 & 1 \\
\hline 28 & $18 / 04 / 05$ & $\begin{array}{l}20: 56: \\
55\end{array}$ & $\begin{array}{l}7 \\
7.3107 \\
93\end{array}$ & $\begin{array}{l}112.66 \\
98\end{array}$ & 0.19 & 1 \\
\hline
\end{tabular}




\begin{tabular}{|c|c|c|c|c|c|c|}
\hline No & Tanggal & Waktu & $\begin{array}{l}\text { Latitu } \\
\text { de }\end{array}$ & $\begin{array}{l}\text { Longitu } \\
\text { de }\end{array}$ & Knot & $\begin{array}{l}\text { Driver } \\
\text { id }\end{array}$ \\
\hline 29 & $18 / 04 / 05$ & $\begin{array}{l}\text { 21:00: } \\
49\end{array}$ & $\begin{array}{l}- \\
7.3108 \\
13\end{array}$ & $\begin{array}{l}112.66 \\
98\end{array}$ & 0.74 & 1 \\
\hline 30 & $18 / 04 / 05$ & $\begin{array}{l}\text { 21:01: } \\
24\end{array}$ & $\begin{array}{l} \\
7.3108 \\
80\end{array}$ & $\begin{array}{l}12.66 \\
98\end{array}$ & 0.22 & 1 \\
\hline 31 & $18 / 04 / 05$ & $\begin{array}{l}\text { 21:01: } \\
58\end{array}$ & $\begin{array}{l} \\
7.3109 \\
00\end{array}$ & $\begin{array}{l}12.66 \\
98\end{array}$ & 0.00 & 1 \\
\hline
\end{tabular}

Berdasarkan data yang didapatkan setelah pengujian statik dilakukan dan data yang telah disimpan yang dapat dilihat pada Tabel 2, dapat disimpulkan pada saat kondisi alat tidak bergerak dan berada di dalam ruangan (indoor) maka perubahan posisi tidak terlalu signifikan, hal ini dapat dilihat dengan tanda perubahan pada posisi latitudenya (valat).

Pada pengujian static ini juga didapatkan bahwa terdapat perubahan yang tidak konsisten pada kecepatannya karena adanya pergeseran posisi pada peta yang mengakibatkan adanya kecepatan yang diukur berdasarkan data yang ditampilkan pada peta dengan data berikutnya yang mucul pada peta, misalnya dengan melihat pada kecepatan(vanot) pada id 23,24,25 pada id 25 tercatat kecepatan sebesar 1.43 kecepatan ini didapatkan berdasarkan pergeseran dari lokasi pemetaan sebelumnya kemudian pada id 23 kecepatan yang tercata berupa 0,00 ini dikarenakan pada saat data diambil tidak adanya pergeseran lokasi maka tidak adanya perubahan kecepatan, kemudian dapat dilihat lagi pada id 22 adanya kecepatan 0.41 ini disebabkan oleh pergeseran lokasi.

Dari hasil statik yang telah diperoleh dapat disimpulkan jika terjadinya penumpukan pada saat berada pada satu posisi yang sama saat tidak adanya pergerakan dari kendaraan. Hal ini terjadi karena pergerakan dari satelit yang mengirimkan koordinat ke dalam alat GPS sim 808 secara terus menerus.

Pengujian dinamik ini dilakukan bertujuan untuk mengetahui apakah sistem dan alat yang dibuat ini dapat berfungsi dengan baik. Tujuan pengujian ini adalah menampilkan kendaraan secara online berdasarkan informasi yang dapat diolah kemudian ditampilkan pada website yang telah dibuat.

Setelah rangkaian sistem disiapkan berfungsi pada kendaraan yang akan diuji coba maka pengambilan data siap dilakukan. Pengambilan data yang telah dilakukan dengan menggunakan skenario sebagai yaitu membandingkan yang akan di dapakan dengan aplikasi WAZE. Pertama-tama menentukan jalur satu arah berupa dari lokasi awal yaitu mulai perumahan wisata bukit mas sampai dengan Universitas Ciputra dengan rute yang didapatkan menggunakan aplikasi WAZE. Aplikasi tersebut memberikan rute tercepat sampai dengan lokasi dapat dilihat pada

Gambar 15 dan pengujian hasil yang didapatkan dapat dilihat pada Tabel 3.

Hasil pengujian dinamik didapatkan bahwa data berupa data tanggal serta waktu kapan pengambilan data tersebut kemudian terdapat lokasi dari alat itu pada peta dengan derajat $\mathrm{x}, \mathrm{y}$ yang ditandakan dengan valat dan valon dapat diambil dan dikirimkan dalam database, termasuk data kecepatan yang didapat pada saat melewati titik yang didapat dari aplikasi WAZE.

Berdasarkan dari data yang ditampilkan dapat disimpulkan data yang didapatkan masih terdapat perbedaan yang singnifikan pada data id no 9 dan 10 yaitu penurunan kecepatan yang sangat drastis padahal kondisi pada saat pengambilan data tersebut tidak ada terjadinya kecelakaan melainkan kemacetan yang disebabkan oleh polisi tidur yang terdapat pada jalan Unesa.

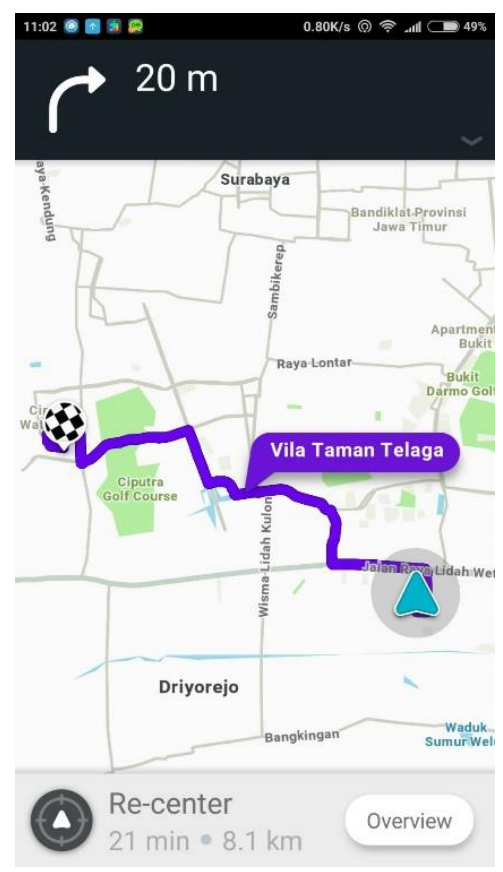


Peter, W, dkk /Journal of Technology and Informatics (JoTI) Vol.1, No.1, Oktober 2019, 31-40

Gambar 15 Rute dari Aplikasi Waze

Tabel 3 Data hasil pengujian dinamik

\begin{tabular}{|c|c|c|c|c|c|c|}
\hline No & Tanggal & Waktu & Latitude & Longitude & Knot & $\begin{array}{l}\text { Driver } \\
\text { id }\end{array}$ \\
\hline 1 & $18 / 04 / 04$ & 11:16:04 & $\begin{array}{l}- \\
7.282597\end{array}$ & 112.6299 & 0.87 & 1 \\
\hline 2 & $18 / 04 / 04$ & 11:17:14 & 7.285082 & 112.6312 & 0.13 & 1 \\
\hline 3 & $18 / 04 / 04$ & $11: 17: 46$ & $\begin{array}{l}- \\
7.285252\end{array}$ & 112.6312 & 0.56 & 1 \\
\hline 4 & $18 / 04 / 04$ & $11: 18: 20$ & 7.285318 & 112.6314 & 0.87 & 1 \\
\hline 5 & $18 / 04 / 04$ & $11: 20: 15$ & $\begin{array}{l}- \\
7.285555\end{array}$ & 112.6312 & 4.37 & 1 \\
\hline 6 & $18 / 04 / 04$ & $11: 20: 49$ & 7.285082 & 112.6314 & 2.19 & 1 \\
\hline 7 & $18 / 04 / 04$ & $11: 21: 22$ & $\begin{array}{l}- \\
7.285125\end{array}$ & 112.6308 & 2.96 & 1 \\
\hline 8 & $18 / 04 / 04$ & $11: 22: 28$ & 7.286345 & 112.6313 & 45.41 & 1 \\
\hline 9 & $18 / 04 / 04$ & $11: 23: 02$ & $\begin{array}{l}- \\
7.286698\end{array}$ & 112.6352 & 37.11 & 1 \\
\hline 10 & $18 / 04 / 04$ & $11: 23: 02$ & 7.289830 & 112.6351 & 1.85 & 1 \\
\hline 11 & $18 / 04 / 04$ & $11: 24: 10$ & 7.289630 & 112.6384 & 29.39 & 1 \\
\hline 12 & $18 / 04 / 04$ & $11: 24: 43$ & 7.288627 & 112.6423 & 57.43 & 1 \\
\hline 13 & $18 / 04 / 04$ & $11: 25: 16$ & 7.288625 & 112.6464 & 34.80 & 1 \\
\hline 14 & $18 / 04 / 04$ & $11: 25: 49$ & 7.290268 & 112.6481 & 48.37 & 1 \\
\hline 15 & $18 / 04 / 04$ & $11: 25: 49$ & $\begin{array}{l}- \\
7.294313\end{array}$ & 112.6489 & 20.24 & 1 \\
\hline 16 & $18 / 04 / 04$ & 11:26:55 & 7.296052 & 112.6517 & 22.22 & 1 \\
\hline 17 & $18 / 04 / 04$ & 11:27:31 & $\begin{array}{l}- \\
7.296688\end{array}$ & 112.6545 & 0.00 & 1 \\
\hline 18 & $18 / 04 / 04$ & $11: 28: 06$ & 7.298007 & 112.6589 & 3.70 & 1 \\
\hline 19 & $18 / 04 / 04$ & $11: 28: 41$ & $\begin{array}{l}- \\
7.299827\end{array}$ & 112.6617 & 3.44 & 1 \\
\hline 20 & $18 / 04 / 04$ & $11: 29: 14$ & $\begin{array}{l}- \\
7.300433\end{array}$ & 112.6642 & 34.72 & 1 \\
\hline 21 & $18 / 04 / 04$ & $11: 29: 47$ & $\begin{array}{l}- \\
7.298833\end{array}$ & 112.6670 & 29.13 & 1 \\
\hline 22 & $18 / 04 / 04$ & $11: 30: 20$ & $\begin{array}{l}- \\
7.298462\end{array}$ & 112.6695 & 18.91 & 1 \\
\hline 23 & $18 / 04 / 04$ & $11: 32: 35$ & $\begin{array}{l}- \\
7.298473\end{array}$ & 112.6727 & 41.13 & 1 \\
\hline 24 & $18 / 04 / 04$ & $11: 32: 35$ & $\begin{array}{l}- \\
7.304672\end{array}$ & 112.6742 & 26.56 & 1 \\
\hline
\end{tabular}

\begin{tabular}{|c|c|c|c|c|c|c|}
\hline No & Tanggal & Waktu & Latitude & Longitude & Knot & $\begin{array}{l}\text { Driver } \\
\text { id }\end{array}$ \\
\hline 25 & $18 / 04 / 04$ & $11: 33: 08$ & $\begin{array}{l}- \\
7.307215\end{array}$ & 112.6743 & 57.80 & 1 \\
\hline 26 & $18 / 04 / 04$ & $11: 33: 41$ & $\begin{array}{l}- \\
7.308825\end{array}$ & 112.6735 & 24.48 & 1 \\
\hline 27 & $18 / 04 / 04$ & $11: 34: 14$ & $\begin{array}{l}- \\
7.308763\end{array}$ & 112.6720 & 20.69 & 1 \\
\hline 28 & $18 / 04 / 04$ & $11: 34: 47$ & $\begin{array}{l}- \\
7.311952\end{array}$ & 112.6714 & 34.72 & 1 \\
\hline 29 & $18 / 04 / 04$ & $11: 35: 20$ & $\begin{array}{l}- \\
7.312760\end{array}$ & 112.6698 & 24.59 & 1 \\
\hline 30 & $18 / 04 / 04$ & $11: 35: 53$ & $\begin{array}{l}- \\
7.310783\end{array}$ & 112.6699 & 0.00 & 1 \\
\hline 31 & $18 / 04 / 04$ & $11: 36: 26$ & $\begin{array}{l}- \\
7.310813\end{array}$ & 112.6699 & 0.00 & 1 \\
\hline 32 & $18 / 04 / 04$ & $11: 36: 59$ & $\begin{array}{l}- \\
7.310797\end{array}$ & 112.6699 & 1.44 & 1 \\
\hline 33 & $18 / 04 / 04$ & $11: 37: 32$ & $\begin{array}{l}- \\
7.310858\end{array}$ & 112.6699 & 0.00 & 1 \\
\hline 34 & $18 / 04 / 04$ & $11: 38: 05$ & 7.310865 & 112.6699 & 0.22 & 1 \\
\hline
\end{tabular}

\section{Kesimpulan}

Secara keseluruhan sistem dapat berfungsi seperti yang di harapkan, pemantauan kendaraan secara online dimana saja dan kapan saja serta kecepatan yang di kendarai oleh pengendara. Dalam pengambilan data menggunakan Arduino IDE terdapat hambatan yang kurang maksimal karena terdapat penumpukan data yang disebabkan oleh $\operatorname{sim} 808$ EVB mengambil data terlalu cepat untuk di akses. Setelah sistem yang diperbaiki dapat mengefisiensikan waktu pengambilan data dari 1.5 menit hingga 30 detik. Sim808 EVB sendiri dapat berfungsi secara maksimal jika berada di luar Gedung seperti lapangan terbuka atau jalan raya.

Penambahan untuk alat SIM EVB ini sendiri terdapat dua versi dengan kode v.3.2 dan v.3.2.2. Terdapat perbedaan versi ini pada v.3.2.2 yaitu ada perintah yang tidak bisa digunakan seperti mengambil data kecepatan maka dari itu sebaiknya menggunakan SIM EVB pada versi v.3.2.

\section{Ucapan Terimakasih}

Terimakasih disampaikan pada Universitas Ciputra yang telah memberikan kesempatan penulis untuk melakukan explorasi penelitian ini sehingga dapat berjalan dengan baik. 
Peter, W, dkk /Journal of Technology and Informatics (JoTI) Vol.1, No.1, Oktober 2019, 31-40

\section{DAFTAR PUSTAKA}

[1] World Health Organization, "Supporting A Decade Of Action," World Heal. Organ. 2013 Glob. Status Road Saftey, vol. 1, p. 318, 2013.

[2] A. D. Saputra, "Studi Tingkat Kecelakaan Lalu Lintas Jalan di Indonesia Berdasarkan Data KNKT (Komite Nasional Keselamatan Transportasi) dari Tahun 2007-2016," War. Penelit. Perhub., vol. 29, no. 2, p. 179, 2018.

[3] RISKESDAS, "Riskesdas 2013 meenn," Jakarta Badan Penelit. dan Pengemb. Kesehat. Dep. Kesehat. Republik Indones., no. Penyakit Menular, p. 103, 2013.

[4] R. Ramani, S. Valarmathy, N. SuthanthiraVanitha, S. Selvaraju, M. Thiruppathi, and R. Thangam, "Vehicle Tracking and Locking System Based on GSM and GPS," Int. J. Intell. Syst. Appl., vol. 5, no. 9, pp. 86-93, 2013.

[5] A. Varade and N. Gajbhiye, "Smart helmet using gsm and gps," Int. Res. J. Eng. Technol., vol. 4, no. 3, pp. 16621667, 2017.

[6] M. Pradhan, "Real-Time Bus Tracking System Using Mobile Application," vol. 17, pp. 4-7.

[7] Y. M. Dinata, Arduino Itu Pintar, 1st ed. Jakarta: PT Elex Media Komputindo, 2016.

[8] V. K. Hazza Alshamisi, "Real- Time Vehicle Tracking System," Int. J. Adv. Res. Electron. Commun. Eng., vol. 6, no. 3, pp. 179-182, 2017. 